\title{
Pengaruh Faktor Sosial dan Tingkat Pendidikan terhadap Keputusan Menjadi Nasabah di BMT Mandiri Ukhuwah Persada (Muda) Jawa Timur
}

\author{
Umi Atia Hanik, Taudlikur Afkar, Hapsari Wiji Utami \\ STAI An Najah Indonesia Mandiri, UIN Sunan Ampel Surabaya \\ Email: umiatiahanik@yahoo.com, taudlikurafkar@yahoo.com, hapsarihap@yahoo.com
}

\begin{tabular}{l}
\hline Article Info \\
\hline Article history: \\
Published: June 28, 2021 \\
Page: 122-132 \\
\hline
\end{tabular}

Keyword:

Faktor Sosial, Tingkat

Pendidikan, Keputusan

Nasabah

\section{Abstract}

Penelitian ini bertujuan untuk menganalisis pengaruh faktor sosial meliputi keluarga, kelompok acuan, peran dan status. Sedangkan Tingkat pendidikan meliputi pendidikan formal, non formal dan informal. Keputusan menjadi nasabah dipengaruhi banyak faktor diantaranya faktor sosial dan tingkat pendidikan. Penelitian ini bermaksud menguji pengaruh faktor sosial dan tingkat pendidikan terhadap keputusan nasabah memilih Bmt Mandiri Ukhuwah Persada (Muda) Jatim. Metode penelitian yang digunakan dalam penelitian ini bersifat kuantitatif. Teknik analisis data menggunakan analisis regresi berganda yang diolah dengan menggunakan statistik SPSS. Hasil penelitian menunjukkan bahwa faktor sosial $84,4 \%$ sedangkan tingkat pendidikan sebesar 4,7\%. Karena penelitian ini menggunakan standar presentase 5\% maka yang berpengaruh hanya tingkat pendidikan.

Kata Kunci : Faktor Sosial, Tingkat Pendidikan, Keputusan Nasabah

\section{Pendahuluan}

Persaingan antar lembaga keuangan saat ini semakin meningkat. Hal ini ditandai oleh semakin banyaknya lembaga keuangan membuka kantor cabang, kantor pembantu, dan kantor kas. Hampir semua bank, bank konvensional maupun syariah melayani mulai segmen korporasi sampai mikro. Bank syariah sebagai follower dibanding bank konvensional menghadapi persaingan yang sangat ketat. Bank syariah tidak hanya bersaing dengan sesama bank syariah, tetapi juga dengan bank konvensional, bank asing dan lembaga keuangan lainnya. Semakin banyaknya jumlah bank maka semakin tinggi tingkat persaingan antara sesama bank itu sendiri. Munculnya dual system dalam perbankan di indonesia yang memungkinkan sebuah bank dijalankan dengan sistem konvensional dan syariah.

\section{Editorial Office:}

Prodi Ilmu Ekonomi Fakultas Ekonomi dan Bisnis Islam, UIN Sunan Ampel Surabaya

Jl. Ahmad Yani 117 Surabaya, Jawa Timur 60237, Indonesia.

Email: oje@uinsby.ac.id 
Oleh sebab itu hampir seluruh bank konvensional saat ini memiliki unit syariah. Disamping itu juga terdapat bank muamalat, bank perkreditan rakyat syariah dan BMT (Baitu Maal Wa Tamwil) syariah.

Berdasarkan studi yang dilakukan oleh Lembaga Riset Teleatika Sharing Vision pada tahun 2013 sebanyak $68 \%$ dari 246,9 juta penduduk Indonesia belum memiliki akun rekening di bank. Oleh karena itu, lembaga keuangan syari'ah yang dalam hal ini adalah BMT, hadir dengan tujuan lebih mendekatkan diri kpada masyarakat dan membantu menyelesaikan persoalan permodalan. Alasan dilakukan penelitian ini karena adanya adanya persaingan yang sangat ketat dikarenakan semakin banyaknya lembaga keuangan syariah saat ini. Agar mampu mensosialkan ke masyarakat luas, maka perusahaan harus mengetahui perilaku konsumen dalam pengambilan keputusan untuk menjadi nasabah lembaga keuangan syariah khususnya BMT MUDA JATIM Surabaya yang berhubungan dengan karakteristik konsumen dan faktor yang mempengaruhi pengambilan keputusan.

Saat ini perkembangan dibidang jasa, khususnya BMT sedang pesat. Dahulu nasabah mencari BMT, sekarang BMT mencari nasabah, maka BMT dituntut mampu menawarkan produk-produk sesuai dengan kebutuhan dan keinginan nasabah. Dengan memanfaatkan produk yang ditawarkan, BMT harus dapat merebut perhatian calon nasabah tidak hanya sekedar memperkenalkan, tetapi juga mengandung unsur persuasi. Salah satu tantangan yang kini masih banyak dihadapi adalah adanya pendapat yang mengatakan BMT syariah hanya sekedar lembaga keuangan yang ditambah label syariah. Alasan dilakukan penelitian ini karena adanya adanya persaingan yang sangat ketat dikarenakan semakin banyaknya lembaga keuangan syariah saat ini. Agar mampu mensosialkan ke masyarakat luas, maka perusahaan harus mengetahui perilaku konsumen dalam pengambilan keputusan untuk menjadi nasabah lembaga keuangan syariah khususnya BMT Muda Surabaya yang berhubungan dengan karakteristik konsumen dan faktor yang mempengaruhi pengambilan keputusan. Karakteristik konsumen terdiri dari profesi, jenis kelamin dan tingkat pendidikan terakhir. Profesi perlu diketahui karena profesi orang berbeda-beda dan mempunyai tingkat upah atau gaji yang berbeda pula. Hal ter: akan berpengaruh terhadap kemam. nasabah dalam menabung. Jenis kelamin perlu diketahui karena sekarang lebih banyak wanita dari pada pria dan wanita cenderung memiliki sifat hemat selain itu di dalam pekerjaan kebanyakan wanita berpenghasilan lebih kecil dari pada pria hal tersebut juga berpegaruh pada besar kecilnya uang yang ditabung. Tingkat pendidikan akhir perlu diketahui karena dengan tingkat pendidikan yang berbeda akan berbeda pula tingkat tabungan dan jenis tabungan yang dipilih.

Ada banyak faktor yang dapat mempengaruhi konsumen, diantaranya menurut Essael yaitu: faktor individual konsumen yang meliputi pendidikan dan penghasilan konsumen, pengaruh lingkungan, dan strategi pemsaran. Dari teori Essael dikatakan faktor individual konsumen yang didalamnya adalah pendidikan sangat mempengaruhi pengambilan keputusan konsumen, hal ini disebabkan konsumen yang berpendidikan tinggi mempunyai pandangan yang berbeda terhadap alternatif produk, informasi produk, dan penilaian terhadap sebuah produk dibandingkan dengan konsumen berpendidikan lebih rendah.

Perilaku konsumen dalam mengambil keputusan juga dipengaruhi oleh faktor sosial seperti kelompok acuan, keluarga, peran dan setatus. Seperti pada teori Kotler juga menyebutkan dalam Simamora bahwa faktor-faktor yang berpengaruh pada perilaku konsumen adalah faktor 
kebudayaan, faktor sosial, faktor personal, dan faktor psikologis.

Meskipun mayoritas penduduk Indonesia beragama Islam, tetapi pengembangan produk syariah berjalan lambat dan belum berkembang sebagaimana halnya lembaga keuangan konvensional. Upaya pengembangan lembaga keuangan syariah tidak cukup hanya berlandaskan kepada aspekaspek legal dan peraturan perundangundangan tetapi juga harus berorientasi kepada pasar atau masyarakat sebagai pengguna jasa (konsumen).

\section{Kajian Pustaka}

Dalam islam dapat dikatakan bahwa pengambilan keputusan adalah suatu proses pilihan yang diambil oleh seorang pemimpin dari berbagai alternatif untuk memecahkan permasalahan yang berdasarkan nilai-nilai islami yaitu Al-Qur'an dan Sunnah Rasul. Berdasarkan pemahaman tersebut dapat kita pahami bahwa menurut islam yang menjadi barometer dalam pengambilan keputusan adalah nilai-nilai islami yakn Al-Qur'an dan Sunnah Rasulullah. Apabila ada hal-hal yang dianggap melanggar islam amaka dapat dikatakan bahwa keputusan tersebut kurang baik. Hal ini bukan berarti islam sangat eksklusif dan tertutup terhadap halhal yang bukan berasal dari islam, harus kita pahami bahwa islam sangat menjunjung tinggi nilai-nilai yang dapat menunjang kehidupan manusia sendiri, seperti demokrasi, hak asasi manusia dan sebagainya.

Salah satu keterangan menyatakan bahwa bila orang mukmin hendak mengadakan perdamaian harus atas dasar persamaan dan adil diantara mereka, pernyataan ini mengandung konotasi bahwa untuk mengadakan perdamaian atau mengambil keputusan itu harus disepakati dan diterima bersama. Hal ini hanya bisa di lakukan dalam satu prosedur yaitu usyawarah diantara mereka. Tanpa musyawah persamaan dan adil itu sulit atau bahkan mustahil bisa dipenuhi, karena hanya dalam musaywarah setiap oran memiliki persamaan hak untuk mendapatkan kesempatan secara adil untuk mengungkapkan pendapat dan pandangan masing-masing terhadap masalah yang sedang dirundingkan.

Apabila dikaitkan dengan masalah pendidikan, maka prinsip musyawarah, saat kira sangat diperlukan terutama dalam setiap menentukan kebijakan mengenai hal-hal yang berkaitan dengan pendidikan. Pemerintah atau pihak sekolah dalam hal ini memiliki hak yang sama dalam menentukan peraturan atau sistem pendidikan yang akan dipakai disetiap lembaga pendidikan nantinya.

Baitul Maal Wa Tamwil (BMT) adalah bank yang beroperasi sesuai dengan prinsipprinsip syariah islam yang tata cara beroperasinya mengacu kepada ketetuanketentuan Al-Qur'an dan Hadist. Baitul Maal Wa Tamwil (BMT) beroperasi mengikuti ketentuan-ketentuan syari'ah islam khususnya yang menyangkut tata cara bermu'amalat secara islam. Dalam tata cara berbermu'amalat itu dijauhi praktek-praktek yang dikhawatirkan mengandung unsurunsur riba untuk diisi dengan kegiatankegatan investasi atas dasar bagi hasil dan pembiayaan perdagangan. Untuk menjamin operasi bank islam tidak menyimpang dari tuntunan syariah, maka pada setiap bank islam hanya diangkat manager dan pimpinan bank yang sedikit banyak menguasai prinsip bermuamalah islam.

Definisi yang lain adalah merupakan kependekan dari baitul maal wa tamwil. Dalam kamus kontemporer Arab-Indonesia, baitul maal diartikan sebagai rumah usaha atau rumah pembiayaan. Baitul maal dikembangkan berdasarkan sejarah perkembangan islam. Dimana baitul maal dikembangkan untuk mengumpulkan sekaligus mentasyarufkan dana sosial. Sedangkan baitul tamwil emrupakan lembaga bisnis yang bermotif laba.

BMT singkatan dari Baitul Maal Wa Tamwil, namun ada juga yang menyebutnya 
sebagai Balai Usaha Mandiri dan Terpadu. Perbedaan penyebutan ini sebenarnya akan menimbulkan penafsiran yang berbeda tentang BMT dilapangan. Dari perkataan Baitul Maal Wa Tamwil maka BMT memiliki 2 visi/misi : yaitu visi/misi sosial yang diwujudkan melalui Baitul Maal, dan visi/misi bisnis yang diwujudkan melalui Baitut Tamwil. Dengan demikian strategi BMT dalam pemberdayaan ekonomi rakyat ini adalah dengan memadukan visi/misi sosial dan bisnis. Dalam segi operasi, BMT tidak lebih dari sebuah koperasi, karena ia dimiliki oleh masyarakat yang menjadi anggotanya, menghimpun simpanan anggota dan menyalurkannya kembali kepada anggota melalui produk pembiayaan / kredit. Oleh karena itu legalitas BMT pada saat ini lebih paling cocok adalah berbadan hukum koperasi. Baitul Maal nya BMT, berupaya menghimpun dana dari anggota masyarakat yang berupa zakat, infaq dan shodaqoh (ZIS) dan disalurkan kembali kepada yang berhak menerimanya, ataupun dipinjamkan kepada anggota yang benarbenar membutuhkan melalui produk pembiayaan qordhul hasan (pinjaman kebajikan/bunga nol persen). Sementara Baitul Tamwil, berupaya menghimpun dana masyarakat yang berupa : simpanan pokok, simpanan wajib, sukarela dan simpananberjangka serta penyertaan pihak lain, yang sifatnya merupakan kewajiban BMT untuk mengembalikannya. Dana ini diputar secara produktif/bisnis kepada para anggota dengan menggunakan pola syariah.

\section{Metode Penelitian}

Pendekatan yang digunakan dalam penelitian ini adalah pendekatan kuantitatif. Penelitian kuantitatif merupakan "penelitian dengan meneliti seberapa besar pengaruh variabel bebas (independent) terhadap variabel terikat (dependent)". Metode penelitian kuantitatif yang digunakan untuk meneliti pada populasi atau sempel tertentu, pengumpulan data menggunakan instrumen penelitian, analisis data bersifat kuantitatif/statistik dengan tujuan untuk menguji hipotesis yang telah ditetapkan.

\section{Hasil dan Pembahasan \\ Uji Reabilitas dan Uji Validitas}

Tabel 1.

Uji reabilitas instrumen variabel Faktor

Sosial $\left(\mathrm{X}_{1}\right)$

Reliability Statistics

\begin{tabular}{|c|c|r|}
\hline & $\begin{array}{c}\text { Cronbach's } \\
\text { Alpha Based } \\
\text { on } \\
\begin{array}{c}\text { Cronbach's } \\
\text { Alpha }\end{array}\end{array}$ & \\
\hline .481 & $\begin{array}{c}\text { Standardized } \\
\text { Items }\end{array}$ & N of Items \\
\hline
\end{tabular}

Tabel 2.

Uji reabilitas instrumen variabel Tingkat Pendidikan $\left(\mathrm{X}_{2}\right)$

Reliability Statistics

\begin{tabular}{|c|c|c|}
\hline $\begin{array}{c}\text { Cronbach's } \\
\text { Alpha }\end{array}$ & $\begin{array}{c}\text { Cronbach's } \\
\text { Alpha Based } \\
\text { on } \\
\text { Standardized } \\
\text { Items } \\
\end{array}$ & $\mathrm{N}$ of Items \\
\hline .875 & .877 & 9 \\
\hline
\end{tabular}

Tabel 3.

Uji reabilitas instrumen variabel Keputusan Konsumen (Y)

\begin{tabular}{|c|c|r|}
\hline \multicolumn{2}{|c|}{ Reliability Statistics } \\
\hline & $\begin{array}{c}\text { Cronbach's } \\
\text { Alpha Based } \\
\text { on } \\
\begin{array}{c}\text { Cronbach's } \\
\text { Alpha }\end{array}\end{array}$ & \\
\hline .363 & $\begin{array}{c}\text { Standardized } \\
\text { Items }\end{array}$ & N of Items \\
\hline
\end{tabular}

Dalam penentuan tingkat reliabilitas suatu instrumen penelitian dapat diterima bila memiliki koefisien alpha besar dari 0,60 seperti yang dikemukakan oleh Nugroho (2005) dan Suyuthi (2005).

Berdasarkan Reliability Statistic diatas, nilai Cronbach's Alpha Sebesar 0,481 untuk variabel faktor sosial $\left(\mathrm{X}_{1}\right)$, nilai Cronbach's Alpha Sebesar 0,875 untuk 
variabel tingkat pendidikan $\left(\mathrm{X}_{2}\right)$, dan nilai Cronbach's Alpha Sebesar 0,363 untuk variabel keputusan konsumen (Y), adalah tidak reliabel. Seperti yang dikemukakan Triton (2006), karena angka Cronbach's Alpha 0,481 dan 0,875 maka untuk variabel faktor sosial $\left(\mathrm{X}_{1}\right)$ dan tingkat pendidikan $\left(\mathrm{X}_{2}\right)$ diartikan sangat reliabel. Dan untuk variabel variabel keputusan konsumen (Y) karena angka Cronbach's Alpha 0,363 berarti tidak reliabel.

Tabel 4.

Uji validitas instrumen variabel Faktor Sosial $\left(\mathrm{X}_{1}\right)$

\begin{tabular}{|c|c|c|c|}
\hline & F Hitung & F Tabel & Validitas \\
\hline Item01 & 0,126 & 0,374 & $\begin{array}{c}\text { Tidak } \\
\text { Valid }\end{array}$ \\
\hline Item02 & 0,353 & 0,374 & $\begin{array}{l}\text { Tidak } \\
\text { Valid }\end{array}$ \\
\hline Item03 & 0,335 & 0,374 & $\begin{array}{l}\text { Tidak } \\
\text { Valid }\end{array}$ \\
\hline Item04 & 0,056 & 0,374 & $\begin{array}{l}\text { Tidak } \\
\text { Valid }\end{array}$ \\
\hline Item05 & 0,381 & 0,374 & Valid \\
\hline Item06 & 0,290 & 0,374 & $\begin{array}{l}\text { Tidak } \\
\text { Valid }\end{array}$ \\
\hline
\end{tabular}

Tabel 5

Uji validitas instrumen variabel Tingkat Pendidikan $\left(\mathrm{X}_{2}\right)$

\begin{tabular}{|c|c|c|c|}
\hline & F Hitung & F Tabel & Validitas \\
\hline Item07 & 0,685 & 0,374 & Valid \\
\hline Item08 & 0,486 & 0,374 & Valid \\
\hline Item09 & 0,894 & 0,374 & Valid \\
\hline Item10 & 0,724 & 0,374 & Valid \\
\hline Item11 & 0,515 & 0,374 & Valid \\
\hline Item12 & 0,709 & 0,374 & Valid \\
\hline Item13 & 0,647 & 0,374 & Valid \\
\hline Item14 & 0,555 & 0,374 & Valid \\
\hline Item15 & 0,383 & 0,374 & Valid \\
\hline
\end{tabular}

Tabel 6

Uji validitas instrumen variabel Keputusan Konsumen (Y)

\begin{tabular}{|c|c|c|c|}
\hline & F Hitung & F Tabel & Validitas \\
\hline Item16 & 0,000 & 0,374 & $\begin{array}{c}\text { Tidak } \\
\text { Valid }\end{array}$ \\
\hline Item17 & 0,021 & 0,374 & $\begin{array}{c}\text { Tidak } \\
\text { Valid }\end{array}$ \\
\hline Item18 & 0,125 & 0,374 & $\begin{array}{c}\text { Tidak } \\
\text { Valid }\end{array}$ \\
\hline Item19 & 0,365 & 0,374 & $\begin{array}{l}\text { Tidak } \\
\text { Valid }\end{array}$ \\
\hline Item20 & 0,207 & 0,374 & $\begin{array}{l}\text { Tidak } \\
\text { Valid }\end{array}$ \\
\hline Item21 & 0,437 & 0,374 & Valid \\
\hline Item22 & 0,494 & 0,374 & Valid \\
\hline Item23 & 0,347 & 0,374 & $\begin{array}{l}\text { Tidak } \\
\text { Valid }\end{array}$ \\
\hline Item24 & 0,216 & 0,374 & $\begin{array}{l}\text { Tidak } \\
\text { Valid }\end{array}$ \\
\hline Item25 & 0,626 & 0,374 & Valid \\
\hline
\end{tabular}

Berdasarkan tabel-tabel diatas, dari beberapa item ada data yang tidak valid sepereti di variabel $\mathrm{X}_{1}$ (faktor sosial) ada item no $1,2,3,4$ dan 5, sedangkan di variabel $\mathrm{X}_{2}$ (tingkat pendidikan) semua data valid karena $F$ Hitung lebing besar dari pada F Tabel, dan variabel Y (keputusan nasabah) ada beberapa item yang tidak valid juga seperti item no 16, 17, 18, 19, 20, 23, 24 dan 25 . Data yang dikatakan tidak valid apabila F Hitung lebih kecil dari F tabel.Data diatas ada yang tidak valid di karenakan responden tidak mengerti maksud dari isi kuesioner yang dikasih oleh peneliti.

Data yang tidak valid tidak bisa dijadikan acuan untuk penelitian selanjutnya namun data yang valid bisa dijadikan sebagai acuan untuk penelitian selanjutnya. Uji Persyaratan Analisis

\section{Uji Normalitas Data}

\section{Tabel 7}

Uji Normalitas Kolmogorv-Smirnov 


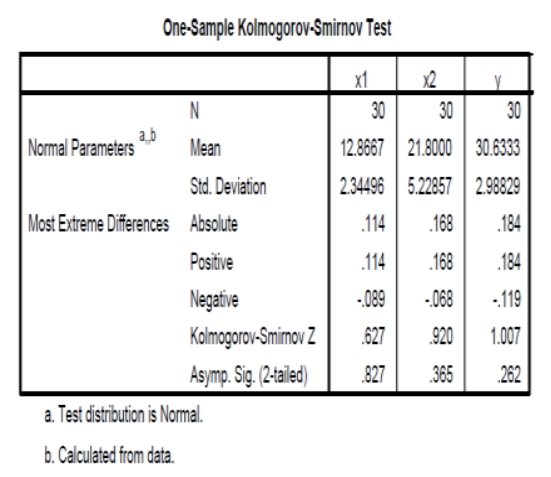

Dari tabel One-Sample KolmogorovSmirnov Test diperoleh angka probabilitas atau Asym. Sig (2-tailed). Nilai ini dibandingkan dengan 0,05 untuk pengambilan keputusan dengan pedoman bahwa, apabila nilai Sig. Atau signifikansi atau probabilitas $<0,05$ distribusi data adalah tidak normal, dan apabila nilai Sig. Atau signifikansi atau nilai probabilitas > 0,05 distribusi data adalah normal. Dari hasil uji normalitas menggunakan OneSample Kolmogorov-Smirnov diperoleh nilai 0,827 untuk variabel faktor sosial, nilai 0,365 untuk variabel tingkat pendidikan dan nilai 0,262 untuk variabel keputusan konsumen berarti distribusi data adalah normal.

Tabel 8

Uji Linieritas

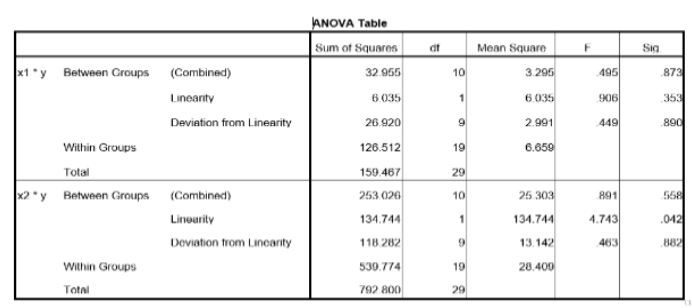

Uji linieritas digunakan untuk mengetahui kelayakan variabel bebas untuk memprediksi variabel terikat. Analisa yang digunakan untuk menguji linieritas adalah Anova. Rumus ini digunakan karena dalam penelitian ini ingin mengetahui apakah ada hubungan linier antara variabel bebas dengan variabel terikat. Untuk mengetahui ada hubungan linier atau tidak dapat dilihat pada tabel Anova dengan melihat perhitungan pada Deviation From Linearity, apabila nilainya menunjukkan > 0,05 maka antara variabel bebas dan variabel terikat mempunyai hubungan linier, dan sebaliknya jika pada Deviation From Linearity, apabila nilainya menunjukkan < 0,05 maka antara variabel bebas dan variabel terikat tidak mempunyai hubungan linier.

Dari hasil uji linieritas diketahui nilai Deviation From Linearity sebesar 0,890 untuk X1 dan 0,882 untuk X2 maka menunjukkan antara variabel bebas dan variabel terikat mempunyai hubungan linier.

\section{Uji Homogenitas/Heterokedasitas}

Tabel 9

Uji Homogenitas/Heterokedasitas

Test of Homogeneity of Variances

\begin{tabular}{|l|r|r|r|r|}
\hline & Levene Statistic & df1 & \multicolumn{1}{c|}{ df2 } & \multicolumn{1}{c|}{ Sig. } \\
\hline$\times 1$ & 4.323 & 7 & 19 & .005 \\
$\times 2$ & 2.271 & 7 & 19 & .074 \\
\hline
\end{tabular}

Uji homogenitas dapat dilakukan dengan menggunakan Levene's Test, dengan melihat taraf signifikansi dari nilai Levene $F_{\text {hitung. Jika nilai Levene }} \mathrm{F}_{\text {hitung }}$ menunjukkan taraf signifikansi lebih dari 0,05 maka dapat dikatakan tidak ada perbedaan varian antar kelompok sampel atau dengan kata lain varian antar kelompok adalah sama. Dari tabel duatas menunjukkan bahwa nilai Levene $F_{\text {hitung menunjukkan taraf }}$ signifikansi kurang dari 0,05 untuk X1 maka dapat dikatakan ada perbedaan variab antar kelompok sampel sedangakan untuk X2 lebih dari 0,05 maka dapat dikatan tidak ada perbedaan varian antar kelompok sampel.

\section{Uji Multikolinearitas}

Tabel 10

Uji Multikolinearitas 


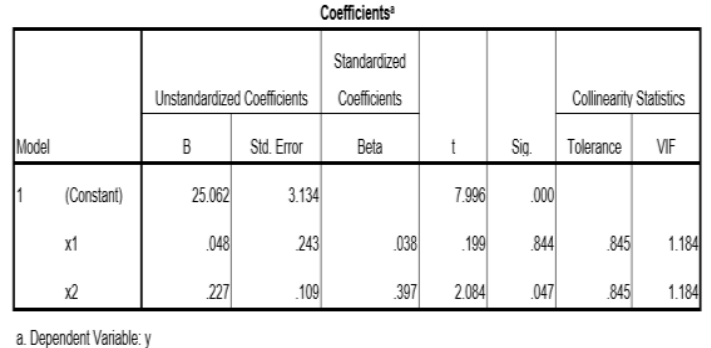

Dari tabel diatas diketahui bahwa:

- Nilai Tolerance semua variabel independen lebih besar dari 0,10

- Nilai VIF semua variabel independen lebih kecil dari 10,00

Berdasarkan nilai diatas, disimpulkan bahwa tidak terjadi Multikolinearitas.

\section{Uji Analisis Regresi Berganda}

\section{Tabel 11}

Uji Regresi Berganda

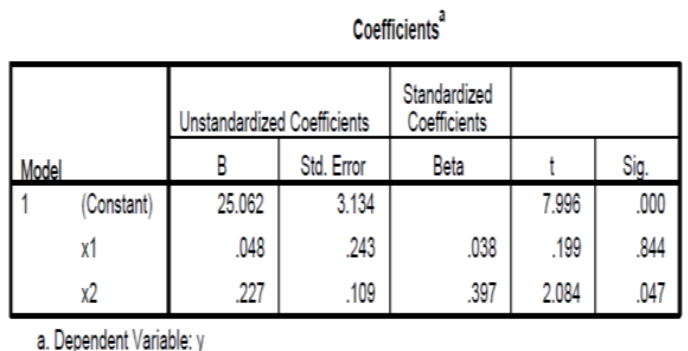

Dari tabel diatas diperoleh persamaan regresi sebagai berikut:

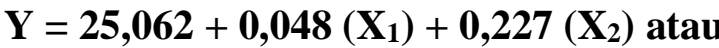
Loyalitas nasabah $=25,062+0,048$ (Faktor Sosial) $+\mathbf{0 , 2 2 7}$ (Tingkat Pendidikan)

Keterangan:

a. Nilai konstanta sebesar 25,062 menyatakan bahwa jika tidak ada faktor sosial dan tingkat pendidikan maka keputisan bernilai 25,062.

b. Koefisien regresi $X_{1}$ sebesar 0,048 menyatakan bahwa setiap penambahan 1 nasabah, faktor sosial akan meningkatkan keputusan nasabah sebesar 0,048. Dan sebaliknya jika faktor sosial menurunkan 1 nasabah, maka keputusan konsumen akan menurun sebesar 0,048.

c. Koefisien regresi $\mathrm{X}_{2}$ sebesar 0,227 menyatakan bahwa setiap penambahan 1 nasabah, tingkat pendidikan akan meningkat keputusan nasabah sebesar 0,227. Dan sebaliknya jika tingkat pendidikan menurunkan 1 nasabah, maka keputusan konsumen akan menurun sebesar 0,227.

\section{Uji Hipotesis}

\section{Uji-t (uji parsial)}

Digunakan untuk menguji apakah pernyataan dalam hipotesis itu benar. Uji-t pada dasarnya menunjukkan seberapa jauh pengaruh suatu variabel independen secara individual dalam menerangkan variabel dependen. Pada tingkat signifikasi $\alpha=5 \%$

Adapun prosedurnya sebagai berikut:

$\mathrm{H}_{0}$ : Artinya tidak terdapat pengaruh yang signifikan dari variabel bebas terhadap variabel terikat.

$\mathrm{H}_{1}$ : Artinya terdapat pengaruh yang signifikan dari variabel bebas terhadap variabel terikat.

Tabel 12

Hasil Uji t-test

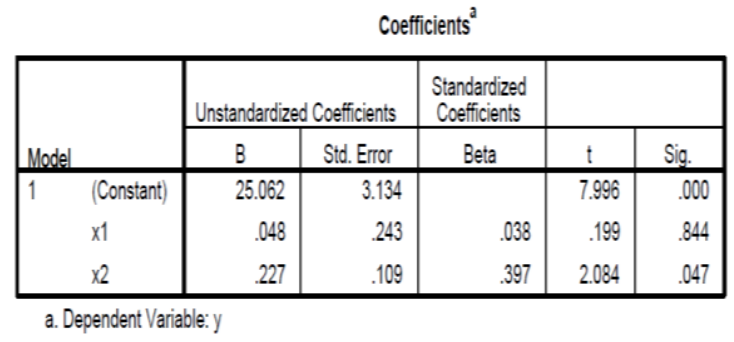

Berdasarkan tabel coefficients regresi diatas dapat dirumuskan sebagai berikut: Untuk rumusan masalah yang pertama dengan hipotesis yang berbunyi "Terdapat pengaruh signifikan antara faktor sosial konsumen terhadap keputusan 
konsumen untuk menjadi nasabah BMT MUDA JATIM Surabaya".

Dengan ketentuan:

$\mathrm{H}_{0} \quad$ : Tidak ada pengaruh dari faktor sosial konsumen terhadap keputusan konsumen untuk menjadi nasabah BMT MUDA JATIM Surabaya.

$\mathrm{H}_{1} \quad$ : Ada pengaruh faktor sosial konsumen terhadap keputusan konsumen untuk menjadi nasabah BMT MUDA JATIM Surabaya.

Nilai tabel coefficients diperoleh nilai sig. Sebesar 0,000 dibandingkan dengan taraf signifikan $(\alpha=5 \%)$ 0,05 maka: Sig. $\alpha 0,844>0,05$

Karena nilai Sig. $>\alpha$ maka disimpulkan untuk menolak $\mathrm{H}_{1}$, yang berarti variabel tingkat sosial tidak berpengaruh signifikan terhadap keputusan nasabah (cara yang lainnya dengan membandingkan antara $t_{\text {hitung }}$ dengan $\left.t_{\text {tabel }}\right)$. Jika $t_{\text {hitung }}<t_{\text {tabel }}$ maka disimpulkan untuk menolak $\mathrm{H}_{1}$, artinya variabel tingkat sosial tidak berpengaruh signifikan terhadap keputusan nasabah (begitu sebaliknya).

\section{Uji F (uji simultan)}

Tabel 13

Hasil Uji F

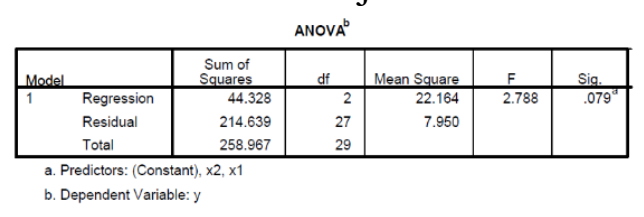

Dari hasil output diatas (ANOVA), terbaca nilai $F_{\text {hitung }}$ sebesar 2,788 dengan tingkat signifikansi 0,079 . Oleh karena probabilitas $(0,079)$ lebih besar dari 0,05 (dalam kasus ini menggunakan taraf signifikansi atau $\alpha=$ $5 \%$ ), maka model regresi bisa dipakai untuk keputusan konsumen.

Umumnya output ini digunakan untuk menguji hipotesis. Hipotesis yang dikemukakan adalah:

$\mathrm{H}_{0}=$ Tidak ada hubungan yang linier antara faktor sosial dan tingkat pendidikan dengan keputusan konsumen.

$\mathrm{H}_{1}=$ Ada hubungan yang linier antara faktor sosial dan tingkat pendidikan dengan keputusan konsumen.

Pedoman yang digunakan adalah: jika Sig. $>\alpha$ maka disimpulkan untuk menolah $\mathrm{H}_{1}$, yang artinya tidak ada hubungan yang linier antara faktor sosial dan tingkat pendidikan dengan keputusan konsumen. Cara lainnya dengan membandingkan nilai $\mathrm{F}_{\text {hitung }}$ dengan $\mathrm{F}_{\text {tabel. }}$ Jika $\mathrm{F}_{\text {hitung }}<\mathrm{F}_{\text {tabel }}$ maka disimpulakan untuk menolak $\mathrm{H}_{1}$, yang antara faktor sosial dan tingkat pendidikan dengan keputusan adalah tidak signifikan.

Untuk rumusan masalah yang kedua dengan hipotesis yang berbunyi "terdapat pengaruh signifikan antara tingkat pendidikan konsumen terhadap keputusan konsumen untuk menjadi nasabah BMT MUDA JATIM Surabaya.

Dengan ketentuan:

$\mathrm{H}_{0} \quad$ : Tidak ada pengaruh antara tingkat pendidikan konsumen untuk menjadi nasabah BMT MUDA JATIM Surabaya.

$\mathrm{H}_{1} \quad$ : Ada pengaruh antara tingkat pendidikan konsumen terhadap keputusan konsumen untuk menjadi nasabah BMT MUDA JATIM Surabaya.

Nilai tabel coefficients diperoleh nilai sig. Sebesar 0,000 dibandingkan dengan taraf signifikan $(\alpha=5 \%)$ 0,05 maka: Sig. $\alpha$ $0,047<0,05$

Karena nilai Sig. $<\alpha$ maka disimpulkan untuk menolak $\mathrm{H}_{0}$, yang berarti variabel tingkat pendidikan berpengaruh signifikan terhadap keputusan konsumen (cara yang lainnya dengan membandingkan antara $t_{\text {hitung }}$ dengan $\left.t_{\text {tabel}}\right)$. Jika $t_{\text {hitung }}>t_{\text {tabel }}$ maka disimpulkan untuk menolak $\mathrm{H}_{0}$, artinya tingkat pendidikan berpengaruh signifikan 
terhadap keputusan nasabah (begitu juga sebaliknya).

\section{Pembahasan Hasil Penelitian}

Tujuan yang dikemukakan dalam penelitian ini adalah untuk menjelaskan:

1. Pengaruh variabel faktor sosial terhadap keputusan menjadi nasabah BMT MUDA JATIM Surabaya.

Dari nilai tabel coefficients ${ }^{a}$ diperoleh nilai thitung sebesar 0,199 dengan nilai Sig. sebesar 0,844, maka Sig. $\alpha 0,844>0,05$. Karena nilai Sig. > 0,05 disimpulkan koefisien regresi faktor sosial adalah tidak signifikan (cara yang lainnya dengan membandingkan antara $t_{\text {hitung }}$ dengan $\left.t_{\text {tabel }}\right)$. Jika $t_{\text {hitung }}<t_{\text {tabel }}$ maka disimpulkan untuk menolah $\mathrm{H}_{1}$, artinya variabel faktor sosial tidak berpengaruh signifikan terhadap keputusan konsumen (begitu juga sebaliknya).

Dengan koefisien regresi $\mathrm{X}_{1}$ sebesar 0,048 menyatakan bahwa setiap penambahan 1, faktor sosial akan meningkatkan keputusan nasabah sebesar 0,048. Dan sebaliknya jika faktor sosial turun 1 maka keputusan konsumen turun 0,048 dengan anggapan $\mathrm{X}_{2}$ tetap.

Hal ini diketahui dari hasil angket yang diberikan kepada responden bahwa faktor sosial yang meliputi kelopmpok referensi, keluarga serta peran sosial dan status bukan menjadi faktor pendorong konsumen untuk menjadi calon nasbah di BMT MUDA JATIM Surabaya. Karena tanpa adanya faktor sosial kenyataanya konsumen sebagai nas BMT MUDA JATIM Surabaya tetap dapat mengetahui adanya BMT MUDA JATIM sebagai lembaga keuangan syariah yang menyediakan jasa untuk memenuhi kebutuhan ekonomi masyarakat (transaksi keuangan) yang berprinsip syariah berupa produk pembiayaan dan simpanan. Begitu juga dengan keluarga dan kelompok acuan juga tidak menjadi faktor pendorong atau alasan mengetahui adamya BMT MUDA JATIM sebagai lembaga keuangan syariah.

Berdasarkan uji analisis regresi berganda nilai konstanta sebesar 25,062 menyatakan bahwa jika tidak ada faktor sosial dan tingkat pendidikan maka keputusan bernilai 25,062.

2. Pengaruh variabel faktor pendidikan terhadap keputusan menjadi nasabah BMT MUDA JATIM Surabaya.

Berdasarkan uji-t (uji persial) nilai tabel coefficients $^{a}$ diperoleh nilai $t_{\text {hitung sebesar 2,084 dengan nilai Sig. }}$ sebesar 0,047, maka sig. $\alpha 0,047<$ 0,05 . karena nilai Sig. $<0,05$ disimpulkan koefesien regresi faktor pendidikan adalah signifikan (cara yang lainnya dengan membanding antara $t_{\text {hitung }}$ dengan $t_{\text {tabel }}$ ). Jika $t_{\text {hitung }}>$ $t_{\text {tabel }}$ maka disimpulkan menolak $\mathrm{H}_{0}$, artinya variabel faktor pendidikan berpengaruh signifikan terhadap keputusan konsumen (begitu juga sebaliknya).

Dan koefesien regresi $\mathrm{X}_{2}$ sebesar 0,397 menyatakan bahwa setiap penambahan 1, faktor sosial akan meningkatkan keputusan nasabah sebesar 0,397. Dan sebaliknya jika faktor sosial turun 1 maka keputusan konsumen turun 0,397 d anggapan $\mathrm{X}_{1}$ tetap.

Hal ini berarti pendidikan formal yang meliputi pendidikan akademis mempengaruhi konsumen dalam pengambilan keputusan untuk menjadi nasabah BMT MUDA JATIM Surabaya.

Adanya hubungan yang erat mengenai faktor pendidikan terhadap keputusan konsumen untuk menjadi nasabah BMT MUDA JATIM Surabaya dalam hal ini dapat dilihat dari jawaban responden pada angket yang diberikan penelit dan hasil pengolahan data angket tersebut. Karena dalam angket tersebut pertanyaan yang menggambarkan jawaban bahwa faktor 
pendidikan yang meliputi pendidikan formal memiliki pengaruh terhadap konsumen dalam mengambil keputusan untuk menjadi nasabah BMT MUDA JATIM Surabaya.

3. Pengaruh variabel faktor sosial dan tingkat pendidikan secara bersama-sama terhadap keputusan menjadi nasabah BMT MUDA JATIM Surabaya.

Berdasarkan hasil output ANOVA

NILAI $F_{\text {hitung }}$ sebesar 2,788 dengan tingkat signifikasi 0,079 . Oleh karena probabilitas $(0,079)$ lebih besar dari 0,05 (Dalam kasus ini menggunakan taraf signifikansi atau $\alpha=$ $5 \%$ ), maka model regresi bisa dipakai untuk keputusan konsumen. Dan dari hasil uji $\mathrm{F}$ diketahui Adjust $R$ Square sebesar 0,110.

\section{Kesimpulan}

Berdasarkan hasil penelitian dan data yang diperoleh oleh peneliti mengenai keputusan konsumen untuk menjadi nasabah BMT MUDA JATIM Surabaya, maka dapat disimpulkan sebagai berikut:

1. Pengaruh variabel faktor sosial terhadap keputusan konsumen untuk menjadi nasabah BMT MUDA JATIM Surabaya

Dari nilai tabel Coefficients diperoleh nilai thitung sebesar 0,199 dengan nilai sig. sebesar $0,844>0,05$ yang berarti $\mathrm{H}_{1}$ ditolak dan $\mathrm{H}_{0}$ diterima, maka tidak ada pengaruh yang signifikan antara faktor sosial terhadap keputusan konsumen.

2. Pengaruh variabel tingkat pendidikan konsumen terhadap keputusan menjadi nasabah BMT MUDA JATIM Surabaya.

Dari nilai tabel Coefficients diperoleh nilai $\mathrm{t}_{\text {hitung }}$ sebesar 2,084 dengan nilai sig. sebesar 0,047 dibandingkan dengan taraf signifikan $(\alpha=0,05 \%) 0,05$ yang berarti $\mathrm{H}_{0}$ ditolak dan $\mathrm{H}_{1}$ diterima, maka ada pengaruh yang signifikan antara tingkat pendidikan konsumen terhadap keputusan menjadi nasabah.

3. Pengaruh variabel faktor sosial dan tingkat pendidikan secara bersamasama terhadap keputusan menjadi nasabah BMT MUDA JATIM Surabaya

Berdasarkan dari hasil uji regresi linier berganda menunjukkan bahwa faktor sosial $\mathrm{X}_{1}$ dan tingkat pendidikan $\mathrm{X}_{2}$ tidak mempunyai pengaruh terhadap pengambilan keputusan konsumen untuk menjadi nasabah BMT MUDA JATIM Surabaya. Dari hasil uji F, nilai $F_{\text {hitung sebesar } 2,788 \text { dengan }}$ tingkat signifikasi 0,079 . Oleh karena probabilitas $(0,079)$ lebih besar dari 0,05 maka model regresi tidak bisa dipakai untuk keputusan konsumen.

\section{Daftar Pustaka}

Arifin, Zainal. 2012. Penelitian Pendidikan. Bandung: PT Remaja Rosdakarya

Arikunto, Suharsimi. (2005). Manajemen Penelitian. Jakarta : PT. Rineka Cipta.

Brosur Baitul Maal Wa Tamwil Mandiri Ukhuwah Persada Jawa Timur (BMT MUDA JATIM)

Budiarti, Rika dkk. (2005). Pengembangan Analisis Multivariate Dengan SPSS 12. Jakarta : Selemba Infotek.

Djarwanto. (1996). Mengenal Beberapa Uji Statistik Dalam Penelitian. Yogyakarta : Liberty.

Ferrinadewi.2004 (dalam Triyani) Pengaruh Sikap Konsumen Terhadap Keputusan Pembelian Handphone Nokia (Skripsi pada jurusan manajemen, fakultas ekonomi, Universitas Islam Negeri Maulana Malik Ibrahim Malang).

Maimunah Hasan. (2012) Pendidikan Anak Usia Dini. (Jogjakarta : Diva Press)

Maria Asti Adhanari. (2005). Pengaruh Tingkat Pendidikan Terhadap Produktivitas Kerja Karyawan Bagian Produksi Pada Maharani Handicraft Di Kabupaten Bantul (Skripsi pada 
Jurusan Ekonomi, Fakultas Ilmu Sosial, Universitas Negeri Semarang)

Muhammad Ridwan. (2004) Manajemen

Baitul Maal Wa Tamwil (BMT). Yogyakarta: UII Press

Muhammad Rusli. (2014). Pengelolaan Statistik Yang Menyenangkan. Yogyakarta : GRAHA ILMU

Trihendradi, Cornelius. (2005). Step by step SPSS 13 Analisis Data Statistik. Yogyakarta: ANDI.

Triyani. (2009) Pengaruh Sikap Konsumen Terhadap Keputusan Pembelian Handphone Nokia (Skripsi pada jurusan manajemen, fakultas ekonomi, Universitas Islam Negeri Maulana Malik Ibrahim Malang)".

Rivai, Veithzal dan Arviyan Arifin. (2010). Islamic Banking. Jakarta: PT Bumi Aksara

Saputro, Wahyu Joko. (2015). Strategi Pengembangan Produk Pembiayaan Murabahah Bait Mal Wa Al-Tamwil Muda Surabaya (Skripsi pada Program Studi Ekonomi Syariah Fakultas Ekonomi dan Bisnis)

Yasri.2012. Analisis Faktor Penentu Menjadi Nasabah Bank Syariah. Jurnal Kajian Manajemen Bisnis. Volume 1, Nomor 2, September 2012 